\title{
Kepastian Hukum Mekanisme Kerja Persekutuan Perdata Notaris Berkaitan Dengan pembuatan Akta
}

\author{
1Debora Natalia Christie Da Costa, E-mail: dacostadebora@ymail.com
}

2Steviedacosta\&partners, E-mail: steviedacosta@yahoo.com

\begin{tabular}{l}
\hline Info Artikel \\
\hline Keywords : \\
The Civil Guild, Notarial Deed \\
\\
\\
Corresponding Author: \\
Costa. E-mail: \\
dacostadebora@ymail.com \\
DOI: \\
10.24843/AC.2018.v03.i02.p07 \\
Persekutuan Perdata, \\
Pembuatan Akta \\
Mekanisme Kerja Notaris \\
Catie Da \\
\end{tabular}

Info Artikel

Keywords :

The Civil Guild, Notarial Deed

10.24843/AC.2018.v03.i02.p07

\begin{abstract}
The Civil Partnership in UUJNP indicates that Notaries can form a forum for cooperation. As time goes by the Notary work system that runs the Notary civil partnership is still questionable its validity, due to the arrangement of the civil partnership as regulated in the provisions of Article 16 paragraph (1) letter (f) and Article 20 paragraph (1), Article 40 UUJNP and 1618 KUH Perdata, not yet completely perfect and there are still deficiencies in implementation. The formulation of the problem, What is the mechanism of work of the Notary who runs the Notary Civil Partnership related to the confidentiality of making the deed according to Article 16 paragraph (1) letter (f) and Article 20 paragraph (1) UUJNP? and Is a legitimate Instrumenter witness who previously testified in the making of a deed by a colleague of the Notary Civil Partnership then reused by another Notary Civil Partnership partner reviewed under Article 40 of the UUJNP ?. This research is Normative Legal Research. The results of the study conclude that the mechanism of the Notary's work that reflects the character of the Notary Profession related to the confidentiality of making a deed in carrying out the Notary Civil Partnership according to Article 16 paragraph (1) letter ( $f$ ) and Article 20 paragraph (1) UUJNP there is still a vague legal norm and the validity of previous Instrumenter witnesses has testified in the making of a deed by a colleague of the Notary Civil Partnership and then reused by other Notary Civil Partnership partners reviewed according to Article 40 of the National Law on Legal Entity, there is still ambiguity or obscurity of legal norms.
\end{abstract}

\begin{tabular}{l}
\hline Abstrak \\
\hline Persekutuan Perdata dalam UUJNP mengindikasikan bahwa \\
Notaris dapat membentuk suatu wadah kerjasama. Seiring \\
berjalannya waktu sistem kerja Notaris yang menjalankan \\
persekutuan perdata Notaris masih dipertanyakan \\
keabsahannya, dikarenakan pengaturan persekutuan perdata \\
yang diatur dalam ketentuan Pasal 16 ayat (1) huruf (f) dan \\
Pasal 20 ayat (1), Pasal 40 UUJN serta 1618 KUH Perdata, \\
belum seutuhnya sempurna dan masih terdapat kekurangan \\
dalam pelaksanaanya. Rumusan permasalahannya, \\
Bagaimanakah mekanisme kerja Notaris yang menjalankan \\
Persekutuan Perdata Notaris terkait kerahasiaan pembuatan \\
akta menurut Pasal 16 ayat (1) huruf (f) dan Pasal 20 ayat (1) \\
UUJNP? dan Apakah sah saksi Instrumenter yang sebelumnya \\
telah bersaksi dalam pembuatan akta oleh rekan Persekutuan \\
Perdata Notaris kemudian digunakan kembali oleh rekan \\
Persekutuan Perdata Notaris lainnya dikaji menurut Pasal 40
\end{tabular}


UUJNP?. Penelitian ini Penelitian Hukum Normatif. Hasil studi menyimpulkan Mekanisme kerja Notaris yang mencerminkan karakter Profesi Notaris terkait kerahasiaan pembuatan akta dalam menjalankan Persekutuan Perdata Notaris menurut Pasal 16 ayat (1) huruf (f) dan Pasal 20 ayat (1) UUJNP masih terdapat kekaburan norma hukum dan Keabsahan saksi Instrumenter yang sebelumnya telah bersaksi dalam pembuatan akta oleh rekan Persekutuan Perdata Notaris kemudian digunakan kembali oleh rekan Persekutuan Perdata Notaris lainnya dikaji menurut Pasal 40 UUJNP masih terdapat ambiguitas atau kekaburan norma hukum.

\section{Pendahuluan}

Undang-Undang Dasar Negara Republik Indonesia Tahun 1945 dalam ketentuan Pasal 1 ayat (3) menentukan bahwa: "Negara Indonesia adalah Negara Hukum. Amanah konstitusional ini menjadi landasan pembentukan segala peraturan perundang-undangan yang ada dibawahnya. Hukum memiliki peran yang sangat sentral dalam membawa ketentraman dan kedamaian perjalanan bangsa ini". Berkembangnya kegiatan perniagaan yang semakin meningkat menyebabkan meningkatnya tuntutan masyarakat untuk pengembangan dunia usaha, mendorongnya untuk mendapatkan kepastian hukum yang membutuhkan pelayanan dari pejabat umum dalam bidang pembuatan alat bukti guna menjamin kepastian hukum dari perbuatan hukum yang dilakukan salah satunya adalah dengan menggunakan Jasa Notaris. ${ }^{1}$

Suatu kegiatan perniagaan yang membutuhkan pelayanan dari pejabat umum dalam hal ini Notaris di bidang pembuatan alat bukti guna menjamin kepastian hukum salah satu contoh konkritnya adalah suatu perjanjian peminjaman kredit yang dilakukan oleh Bank dengan Nasabah atau debiturnya. Notaris pada awal pengaturannya diatur dalam Peraturan Jabatan Notaris staatsblad 1860-3 (untuk selanjutnya disebut sebagai PJN). Dalam sebuah pasal PJN yaitu pasal 1 memberikan suatu arti tentang notaris itu sendiri yaitu notaris ialah seorang pejabat umum yang dimana satu satunya berwenang yang membuatkan akta otentik tentang semua perjanjian, perbuatan dan ketetapan yang telah diharuskan oleh suatu peraturan umum atau yang telah dikehendaki agar yang telah berkepentingan dikehendaki oleh peraturan umum yang telah dinyatakan dalam suatu akta otentik, untuk menjamin juga tentang kepastian tanggal, juga memberikan grosse, pada suatu salinan maupun kutipan dalam pembuatan akta oleh peraturan umum.

Notaris yang berada di Indonesia perjalanannya sering mengalami adanya suatu perkembangan di dalam bangsa Indonesia itu sendiri. PJN ini kemudian dirubah sesuai dengan adanya sebuah Undang-Undang Nomor 30 Tahun 2004

1Herlien Budiono, (2013), Dasar Teknik Pembuatan Akta Notaris,PT. Citra Aditya Bakti, Bandung, h. 1. 
tentang Jabatan Notaris (yang selanjutnya disebut dengan UUJN). ${ }^{2}$ Dengan adanya UUJN, maka sangat diharapkan untuk memberikan satu adanya perlindungan hukum yang baik untuk masyarakat maupun untuk notaris itu sendiri. Undang-undang ini kemudian mengalami perubahan dengan disahkannya Undang-Undang Nomor 2 Tahun 2014 tentang Perubahan atas Undang-Undang Nomor 30 Tahun 2004 tentang Jabatan Notaris. Di dalam Pasal 16 ayat (1) huruf (f) UUJNP yang dimana notaris untuk diwajibkan merahasiakan dalam segala apapun mengenai sebuah akta yang telah di buatnya sesuai dengan keterangan yang telah di perolehnya kepada para pihak karena notaris memegang sumpah jabatannya, yang terkecuali undang-undang menentukan lain. Dengan adanya kode etik sangat bertujuan untuk suatu profesi yang di jalankan dengan adanya moral dan martabat serta motivasi dan argumentasi secara rasional dan kritis untuk menjunjung tinggi nilai-nilai dalam norma tersebut. ${ }^{3}$ Pasal 20 UUJNP dimana mengatur notaris yangsudah menjalankan jabatannya haruslah memperhatikan kemandirian dan juga tidak memihak dalam menjalankan suatu jabatannya dalam bentuk persekutuan perdata,bentuk yang telah di maksudkan berdasarkan adanya ketentuan peraturan perundang-undangan dan ketentuan-ketentuan lainnya juga dalam persekutuan perdata sebagaimana telah di aturnyatentang sebuah persyaratan didalam menjalankan sebuah jabatan noatris dalam bentuk peraturan menteri sebagai peraturan pelaksanaan dari pasal 20 UUJNP, dan juga ditetapkanlah Peraturan Menteri Hukum Dan Hak Asasi Manusia Republik Indonesia Nomor M.HH.01.AH.02.12 Tahun 2010 tentang Persyaratan Menjalankan Jabatan Notaris Dalam Bentuk Perserikatan Perdata.

suatu ketentuan yang telah mebuat aturan dimana bahwa notaris yang ada di Indonesia yang telah menjalankan suatu jabatannya dalam sebuah bentuk persekutuan perdata notaris yang telah merupakan suatu upaya untuk pemerintahan agar mendukung peningkatan dalam sebuah pelayanan bagi setiap masyarakat di Indonesia dalam bidang kenotariatan dan membuat peningkatan pengetahuan yang akan disertakan keahlian bagi para notaris yang ada.

Berdasarkan sebuah konsep dalam persekutuan perdata yang ada di UUJNP, maka mengindikasikan bahwa notaris dapat juga membentuk suatu wadah dalam kerja sama dan dalam suatu pembentukan untuk persekutuan perdata notaris dimana sangat diharapkan untuk memaksimalkan suatu pemberian dalam pelayanan pada publik.dapat juag berbagi ilmu dan pengalaman yang ada dalam satu kantor yang sama bagi para notaris.

\footnotetext{
${ }^{2}$ Sari, Y., Muljono, S., \& Kontesa, E. (2017). Kedudukan Jabatan Notaris Dalam Bentuk Persekutuan Perdata Notaris Setelah Berlakunya Undang-Undang Nomor 2 Tahun 2014 Tentang Perubahan Atas Undang-Undang Nomor 30 Tahun 2004 Tentang Jabatan Notaris (Doctoral Dissertation, Universitas Bengkulu).

3I Dwi Andika Prayojana, (2017), Pelaksanaan Penyelesaian Pelanggaran Kode Etik Notaris TentangPemasangan Papan Nama Notaris Di Kota Denpasar, Mahasiswa Magister Kenotariatan Fakultas Hukum Udayana, Bali.
} 
Pengaturan persekutuan perdata baik yang diatur dalam ketentuan Pasal 16 ayat (1) huruf (f) dan Pasal 20 ayat (1), Pasal 40 UUJNP serta 1618 KUH Perdata, belum seutuhnya sempurna dan masih terdapat kekurangan dalam pelaksanaannya. Di sini masih terdapat adanya suatu kekaburan norma hukum pada ketentuan pasal diatas terkait dengan mekanisme kerja Notaris yang mencerminkan karakter Profesi Notaris dalam menjalankan Persekutuan Perdata Notaris terkait kerahasiaan pembuatan akta serta keabsahan saksi Instrumenter yang sebelumnya telah bersaksi dalam pembuatan akta oleh rekan Persekutuan Perdata Notaris kemudian digunakan kembali oleh rekan Persekutuan Perdata Notaris lainnya mengingat surat keputusan pengangkatan Notaris adalah bersifat perseorangan/mandiri. Peraturan Menteri Hukum dan Hak Asasi Manusia Republik Indonesia Nomor M.HH.01.AH.02.12 Tahun 2010 tentang Persyaratan Menjalankan Jabatan Notaris dalam Bentuk Perserikatan Perdata (selanjutnya disebut Permen kumham) yang berfungsi sebagai peraturan pelaksanaan ketentuan Pasal 20 UUJNP juga masih terdapat kekaburan norma hukum terkait hal di atas dan hanya dijelaskan dalam ketentuan Pasal 1 angka 1 bahwa perserikatan perdata notaris ialah perjanjian yang dimana notaris yang menjalankan sebuah jabatan pada masing-masing pihak sebagai notaris dengan mendirikan dan untuk mengurus serta gabung di dalam satu kantor bersama notaris lainnya. Pasal ini masih memberikan ruang penafsiran dan belum memberikan ketegasan kejelasan arti. Beranjak dari adanya kekaburan norma hukum yang terdapat di dalam ketentuan Pasal 16 ayat (1) huruf (f), Pasal 20 ayat (1), Pasal 40 UUJN Peserta di dalam peraturan pelaksananya yakni dalam ketentuan Pasal 1 angka 1 Peraturan Menteri Hukum dan Hak Asasi Manusia Republik Indonesia Nomor M.HH.01.AH.02.12 Tahun 2010, maka penulis berinisiatif untuk mengangkat suatu judul penelitian "Kepastian Hukum Mekanisme Kerja Persekutuan Perdata Notaris Berkaitan dengan Pembuatan Akta"

Rumusan masalah di dalam penelitian ini ialah :

1. Bagaimana mekanisme kerja Notaris yang menjalankan Persekutuan Perdata Notaris terkait kerahasiaan pembuatan akta menurut Pasal 16 ayat (1) huruf (f) dan Pasal 20 ayat (1) UUJNP?

2. Bagaimana keabsahan saksi Instrumenter yang sebelumnya telah bersaksi dalam pembuatan akta oleh rekan Persekutuan Perdata Notaris kemudian digunakan kembali oleh rekan Persekutuan Perdata Notaris lainnya dikaji menurut Pasal 40 UUJNP?

Penelitian ini bertujuan untuk dapat mengembangkan ilmu hukum, khususnya di bidang hukum Kenotariatan dan mengenai kepastian hukum mekanisme kerja notaris yang menjalankan persekutuan perdata notaris dalam pembuatan akta. Sesuai dengan rumusan masalah yang akan dibahas dalam ini, maka adapun tujuan khusus dari penelitian ini yaitu untuk dapat mengetahui serta untuk menganalisis mengenai mekanisme kerja Notaris yang mencerminkan karakter Profesi Notaris dalam menjalankan Persekutuan Perdata Notaris terkait kerahasiaan pembuatan akta menurut Pasal 16 ayat (1) huruf (f) dan 
Pasal 20 ayat (1) UUJNP dan untuk memahami dan menganalisis keabsahan saksi Instrumenter yang sebelumnya telah bersaksi dalam pembuatan akta oleh rekan Persekutuan Perdata Notaris kemudian digunakan kembali oleh rekan Persekutuan Perdata Notaris lainnya dikaji menurut Pasal 40 UUJNP

\section{Metode Penelitian}

Metode penelitian dapat diartikan sebagai proses prinsip-prinsip dan tata cara untuk memecahkan suatu permasalahan dalam suatu penelitian. Sui Generis di dalam istilah hukum ialah ilmu yang merupakan jenis dalam hal cara kerja dan sistem ilmiah. Penelitian ini sesuai dengan karakter "sui generis" karena itu maka penelitian ini memfokuskan pada bahan-bahan hukum yang berkaitan dengan adanya pokok-pokok permasalahan yang ada. Suatu Bahan hukum yang sudah di gunakan untuk sebuah penyusunan dan pembahasan dalam permasalahan penelitian ini yaitu menggunakan sebuah metode dalam suatu penelitian hukum yang normative yaitu beranjak dari adanya suatu kekaburan norma didalam penelitian ini yaitu terlihat dalam ketentuan pasal 16 ayat (1) huruf (f), Pasal 20 ayat (1) dan Pasal 40 UUJNP.

Adapun penggunaan suatu bahan hukum primer dan bahan hukum sekunder dalam penelitian ini yaitu hukum normatif, maka telah di uraikan sebagai berikut :

1. Bahan Hukum Primer.

Bahan hukum ini yaitu bahan hukum yang dimana terdiri dalam sebuah aturan perundang-undangan dan juga catatan resmi dalam putusan hakim. Bahan hukum tersebut juga dimana sifatnya telah menggunakan bahan hukum yang sifatnya mengikat terutama berpusat pada perundang-undangan yang berlaku di seluruh Indonesia. ${ }^{4}$

2. Bahan Hukum Sekunder.

Bahan hukum ini memberikan sebuah penjelasan yang dimana terdiri dalam beberapa buku hukum, karya tulis, jurnal hukum, dan pandangan-pandangan sebuah para ahli yang telah dimuat dalam media masa, kamus dan juga internet yang menyebutkan nama dan juga situsnya tersebut.

Pada metode pengumpulan dalam bahan hukum yang telah di pergunakan dalam cara penulisan ini yaitu teknik bola salju (snowball method). Sebuah metode ini dimana ibaratnya yaitu telah seperti bola yang menggelinding terus terusan sampai akhirnya menemukan sebuah titik jenuh, hal ini telah mengacu pada aturan perundang-undangan dan juga buku didalam daftar pustaka tersebut.kumpulan bahan hukum primer,sekunder dan juga tersier telah diklasifikasi secara sistematis yang sesuai dengan titik masalah yang telah

${ }^{4}$ H. Zainuddin Ali, (2009), Metode Penelitian Hukum, Sinar Grafika, Jakarta, h.47 
dibahas didalam sebuah penelitian ini. ${ }^{5}$ Pengklasifikasian ini sangat di harapkan untuk dapat untuk mempermudah seseorang melakukan suatu analisis pada permasalahan yang terjadi dan menjadi suatu objek di dalam penelitian yang telah mengelaborasikan antara suatu bahan hukum primer, sekunder dan juga tersier dan telah tersusun dan dianalisis juga secara tersusun dan benar.

Pada teknis analisis bahan hukum yang ada dalam menggunakan teknik deskripsi, teknik interprestasi, dan juga teknik evaluasi. Teknik deskripsi ialah teknik dasar pada analisis yang tidak dapat terhindari pada penggunaanya. Deksripsi ialah uraian yang apa adanya terhadap sesuatu kondisi atau seperti posisi dari proposisi hukum maupun non hukum. Teknik interpretasi yang berupa penggunaan jenis-jenis penafsiran di dalam ilmu, historis, sistematis, kontektual dll. Teknik evaluasi yaitu sebuah penilaian yang berupa tepat atau tidak tepat, benar ataupun salah, sah maupun juga tidak terhadap pada suatu keputusan yang benar yang ada pada suatu bahan hukum primer maupun didalam bahan hukum sekunder itu sendiri.

Analisis hukum terkait dengan kekaburan norma hukum dalam laporan penelitian ini terkait dengan kekaburan norma hukum yang terdapat dalam ketentuan Pasal 16 ayat (1) huruf (f), Pasal 20 ayat (1) serta Pasal 40 UUJNP dilakukan dengan menggunakan teknik interpretasi dengan jenis penafsiran gramatikal, penafsiran sistematis dan teknik evaluasi. Pada suatu Penafsiran gramatikal atau pada tata Bahasa ialah suatu jenis penafsiran yang dimana mencari makna di dalam ketentuan undang-undang atau yang dari pemakaiannya secara teknik yuridis.

\section{Hasil Dan Pembahasan}

\subsection{Mekanisme Kerja Notaris Yang Mencerminkan Karakter Profesi Notaris Dalam Menjalankan Persekutuan Perdata Notaris Terkait Kerahasiaan Pembuatan Akta Menurut Pasal 16 Ayat (1) Huruf (F) Dan Pasal 20 Ayat (1) UUJNP.}

Dalam UUJNP persekutuan perdata yang telah diatur telah bertujuan tidak hanya untuk menjalankan perusahaan yang artian komersial, keuntungannya juga bukan hanya menjadi bagian dan orientasi di dalam menjalankan profesinya itu sendiri. Tidak hanya dapat dikatakan menjalankan perusahaannya saja tapi melainkan juga yang artinya berkantor bersama. Yang kemudian di dalam praktik persekutuan perdata notaris yang telah di konsepkan bentuk kerja sama yang terjadi dimana dua ataupun bisa lebih dari dua notaris yang akan menyewakan sebuah kantor

5I Made Wahyu Chandra Satriana, 2013, Kebijakan Formulasi Keadilan Restoratif Dalam Sistem Peradilan Pidana, (tesis) Program Studi Magister (S2) Ilmu Hukum Universitas Udayana, Denpasar, h.36 
atau gedung yang sama dan termasuk menempati bangunan tersebut bersama-sama dengan membagi ruangan pada masing-masing notaris dalam persekutuan perdata, klien diharapkan dapat memilih secara bebas dengan siapa dia mau menggunakan jasa notaris. ${ }^{6}$

Kewenangan Notaris dalam ketentuan UUJNP berdasarkan ketentuan Pasal 15 yaitu dimana notaris yang telah menjalankan profesi tugas dan jabatannya tidak juga luput dari kekeliruan ataupun kesalahan baik penyebabnya yang tidak professional maupun juga telah memihak salah satu pihak hingga terjadi suatu permasalahan di dalam akta tersebut yang telah dibuatnya notaris. Sabagai notaris ataupun pejabat yang berwenang dalam pembuatan akta otentik dimana sering kali tindakkannya itu tidak berhati - hati yang akibatnya menimbulkan permasalahan hukum yang baik permasalahan hukum perdata maupun permasalahan hukum pidana. ${ }^{7}$

Akta dimana sebagai fungsi formal yang dimana suatu perbuatan hukum yang akan menjadi lengkap apabila telah dibuat akta dalam pasal $1767 \mathrm{KUH}$ perdata dimana sebagai syarat formal dalam perbuatan hukum yang mengenai suatu perjanjian hutang piutang, Yang dimana merupakan fungsi akta lainnya sebagai alat pembuktian. Akta otentik sangat diperlukan untuk para pihak yang terikat di dalam suatu perjanjian guna untuk sebagai alat pembuktian di kemudian harinya. ${ }^{8}$

Di dalam pembuktian yang mempunyai suatu arti yuridis yang dimana berlakunya untuk para pihak yang berperkara atau mempunyai sebuah hak dari mereka dan tujuan juga dari sebuah pembuktian yaitu telah memberikan sebuah kepastian pada hakim dimana tentang adanya sebuah kejadian. Dalam membuktikan haruslah dilakukan oleh setiap pihak yang bersangkutan dan telah disebutkan sebagai beban pembuktian dimana bahwa barang siapa yang menyatakan haknya itu, maka orang itu haruslah membuktikan bahwa memang benar adanya kejadian tersebut. Tujuan dari suatu akta otentik yang akan di uraikan oleh Teguh Samudra, yaitu:

1. Untuk menyatakan suatu perbuatan hukum dimana akta tersebut merupakan suatu syarat yang sangat mutlak bagi adanya suatu perbuatan hukum tertentu. Seperti halnya pendirian perseroan terbatas dan perubahan anggaran dasar dari perseroan terbatas.

\footnotetext{
${ }^{6}$ Zakhina, I. (2016). Karakteristik Dan Bentuk Persekutuan Perdata Notaris. Kumpulan Jurnal Mahasiswa Fakultas Hukum.

7Sinuhaji, Z. B. Y. (2015). Persekutuan Perdata Menurut Undang-undang Nomor 2 Tahun 2014 Tentang Perubahan Atas Undang-undang Nomor 30 Tahun 2004 Tentang Jabatan Notaris dan Kitab Undang-undang Hukum Perdata terhadap Prinsip Kemandirian Notaris. Kumpulan Jurnal Mahasiswa Fakultas Hukum.

${ }^{8}$ Kindyawati, E. (2015). Tanggung Jawab Notaris Dalam Persekutuan Perdata Terhadap Pembuatan Akta. Kumpulan Jurnal Mahasiswa Fakultas Hukum.
} 
2. Dimana sebagai sesuatu alat pembuktian yang dimana suatu kehendak dari pihak yang telah membuat perjanjian tersebut dibuat secara benar seperti yang ada dalam perjanjian kerjasama maupun jual beli.

Akta otentik yang merupakan produk dari Notaris kerahasiaannya dijaga dan dilindungi oleh undang-undang. Hal ini ditentukan secara spesifik dalam Pasal 16 ayat (1) huruf f UUJNP dalam salah satu ketentuan yang pasalnya Notaris diwajibkan untuk merahasiakan tentang suatu keterangan yang telah diperoleh dama pembuatan akta yang telah dibuatnya sesuai dengan janji dan sumpah jabatannya itu sendiri, terkecuali bila pada undang-undang yang telah menentukan lain. Dalam suatu kewajiban untuk merahasiakan segala apapum yang berhubung dengan akta maupun suratsurat lainnya juga untuk melindungi sebuah kepentingan klien atau juga untuk semua pihak yang terkait dalam proses pembuatan akta tersebut.

Pasal 20 ayat (1) UUJNP untuk para Notaris yang telah menjalankan suatu jabatan dalam suatu bentuk persekutuan perdata dengan memperhatikan suatu kemandirian dan tidak adanya keberpihakkan dalam menjalani jabatannya. ${ }^{9}$ Pasal 16 ayat (1) huruf f dan Pasal 20 ayat (1) UUJNP di atas masih terdapat kekaburan norma hukum terkait dengan pengaturan mekanisme kerja Notaris yang mencerminkan karakter profesi Notaris dalam menjalankan persekutuan perdata Notaris terkait kerahasiaan pembuatan akta. Wajib menjaga kerahasiaan akta ini belum dijelaskan sejauh mana arti kata "rahasia" mengingat Notaris yang menjalani persekutuan perdata secara tidak langsung akan mengetahui isi akta yang dibuat oleh rekan persekutuan perdatanya serta apakah Notaris yang menjalani persekutuan perdata apabila tidak diperjanjikan sebelumnya dalam perjanjian pembentukan Persekutuan Perdata dapat diklasifikasikan kepada para pihak yang telah terkait dalam sebuah proses pembuatan akta tersebut. Dalam teori kepastian hukum agar tidak terdapat kekaburan norma hukum hendaknya UUJNP terkait ketentuan pasal di atas memuat dua hal yaitu:

1) Sebuah aturan yang sifatnya umum yang akan membuat individu untuk mengetahui perbuatan apa saja yang bisa maupun tidak bisa untuk di lakukan.

2) Keamanan yang berupa hukum bagi setiap orang atau individu dari dalam kesewenang-wenangan pemerintah yang karena aturan sifatnya umum dapat mengetahui apa aja yang dibebankan dan tidak dibebankan. ${ }^{10}$

\footnotetext{
9Syarif , A. (2017). Akibat hukum Kepailitan Persekutuan Perdata Notaris Terhadap Notaris Persekutuan (Doctoral dissertation, Universitas Airlangga)

10Peter Mahmud Marzuki, (2008), Pengantar Ilmu Hukum, Kencana Prenada Media Group,Jakarta, h. 137
} 
Dua substansi Teori Hukum diatas ke depannya dapat digunakan untuk melakukan pembenahan terkait dengan mekanisme kerja Notaris yang mencerminkan karakter profesi Notaris dalam menjalankan Persekutuan Perdata Notaris terkait kerahasiaan pembuatan akta. Dengan penafsiran secara gramatikal, sistematis dan evaluasi, UUJNP dan Permen kumham yang menjadi peraturan pelaksananya belum mengakomodir secara lengkap dan jelas tentang mekanisme Persekutuan Perdata Notaris yang menceminkan karakter Profesi Notaris terkait kerahasiaan akta.

\subsection{Analisa Yuridis Saksi Instrumenter Yang Sebelumnya Telah Bersaksi Dalam Pembuatan Akta Oleh Rekan Persekutuan Perdata Notaris Kemudian Digunakan Kembali Oleh Rekan Persekutuan Perdata Notaris Lainnya.}

Negara Republik Indonesia adalah Negara Hukum sesuai yang ditetapkan dalam Pasal 1 ayat (3) Undang-undang Dasar Negara Republik Indonesia Tahun 1945 ditentukan bahwa pada kekuasaan akan tunduk dengan hukum yang ada. Didalam Negara hukum, yaitu hukum itu sendiri juga mempunyai suatu kedudukan yang dimana paling tinggi dalam sebuah pemerintahan yang ada. Hukum itupun sendiri mempunyai sebuah kedudukan yang dimana kedudukan tersebut adalah titik perlindungan pada masyarakat. Hukum tersebut mengatur segala sesuatu yang telah berhubungan dengan orang ke orang lainnya maupun dengan kelompok orang ataupun pemerintah.

Adapun sebagai contoh yang dimana sebuah profesi hukum yang telah dimaksud yaitu notaris dimana Pasal 1 angka 1 UUJNP menentukan dimana para notaris adalah pejabat umum yang berwenang membuat suatu akta otentik dan juga kewenangan lainnya yang sebagaimana dimaksud di dalam undang - undang lainnya. Sebagai salah satu notaris profesional yang telah ada di Indonesia dan juga mempunyai sebuah peran dalam gerakan pembangunan secara nasional dan juga semakin kompleks juga pada bidang hukum itu sendiri. Didalam rangka untuk menjalankannya profesi tersebut, notaris yang telah wajib di lindungi oleh hukum yang telah berlaku, disini sangat diperlukan juga untuk menjalankan profesi yang ada atau pun yang berlaku. Ada juga bentuk dari salah satu perlindungan yang diberikan oleh undang-undang untuk notaris sehubungan dengan pembuatan akta otentik yang dimana adanya suatu saksi sesuai juga dengan pasal 40 UUJNP yang dimana hadir dan juga untuk menyaksikan secara langsung dalam pembuatan akta otentik dari para notaris yang sebagaimana dikenal oleh saksi instrumenter. ${ }^{11}$

Pada ketentuan Pasal 20 dan Pasal 40 UUJNP diatas masih terdapat kekaburan norma hukum terkait dengan keabsahan saksi instrumenter yang

11Yuniati, S. (2017). Mekanisme Pemberian Sanksi Terhadap Notaris Yang Melakukan

Pelanggaran Kode Etik Jabatan Notaris. Jurnal Akta 
sebelumnya telah bersaksi dalam pembuatan akta oleh rekan Persekutuan Perdata Notaris kemudian digunakan kembali oleh rekan Persekutuan Perdata Notaris lainnya.

Teori Pembentukan Norma Hukum menyatakan bahwa suatu aturan hukum yang dibentuk hendaknya mendeskripsikan:

1. Hukum ialah ketentuan normatif tertentu dari hukum yang terdiri dari sebuah aturan atau sebagai norma dari sebuah sistem hukum tertentu;

2. Hukum merupakan abstraksi dari apa yang tampak. Jika kita melakukan abstraksi kita merujuk padahal-hal konkret atau dapat diamati. Bagaimana kita dapat mengenali sesuatu kalau tidak memiliki gambaran untuk membimbing kita. Oleh karena itu kita harus beranjak dari yang khusus dulu yakni Hukum atau Sistem Hukum.

3. Hukum adalah suatu sistem hukum tertentu secara menyeluruh dan koheren yang terdapat dalam suatu masyarakat atau negara tertentu;

4. Hukum adalah ide atau konsep umum tentang lembaga-lembaga hukum yang diabstraksikan dari peristiwa-peristiwa tertentu;

Pasal 20 dan Pasal 40 UUJNP terkait dengan keabsahan saksi Instrumenter yang sebelumnya telah bersaksi dalam pembuatan akta oleh rekan Persekutuan Perdata Notaris yang kemudian digunakan kembali oleh rekan Persekutuan Perdata Notaris lainnya masih terdapat kekaburan norma hukum dan belum memenuhi 4 poin dari Teori Pembentukan Norma hukum di atas, mengingat surat keputusan pengangkatan Notaris adalah bersifat berdiri sendiri/mandiri. UUJNP perlu dilakukan pembenahan kedepannya dan hal ini dapat dilakukan dengan menggunakan sarana politik hukum. Politik hukum juga merupakan legal policy atau yang dilaksanakan secara nasional oleh para pemerintah yang terdiri dari sebuah pembangunan hukum pada sebuah pembuatan dan juga pembaharuan sebuah materi hukum agar supaya kebutuhan pelaksanaan ketentuan hukum yang telah ada termasuk juga penegasan fungsi lembaga dan pembinaan para penegak hukum. Lingkup pengertian tersebut terlihat dalam politik hukum yang mencakup sebuah proses pembuatan dan pelaksanaan. Syarat seorang saksi diatur dalam ketentuan Pasal 40 UUJNP ditentukan bahwa:

1) Saksi sebagaimana yang telah dimaksudkan pada ayat (1) :

a. Yang mana sudah menikah ataupun dimana paling rendah berumur delapanbelas tahun;

b. Cakap dalam melakukan sebuah perbuatan hukum ;

c. Mengerti bahasa yang telah dipergunakan ;

d. Dimana membubuhkan sebuah paraf dan tanda tangan;

2) Tidak ada hubungan darah dalam garis lurus ke atas atau ke bawah tanpa suatu pembatasan derajat dan garis ke samping juga sampai dengan derajat ketiga dengan notaris ataupun para pihak. 
3) Dimana seorang saksi yang dimaksud telah dikenal oleh notaris atau telah diperkenalkan pada notaris atau telah diterangkan tentang identitas saksi dan kewenangan juga oleh penghadap.

4) Setiap Akta yang telah dibacakan oleh Notaris dihadiri 2 (dua) orang saksi paling sedikit, kecuali peraturan perundang-undangan menentukan lain.

Ketentuan yang ada hanya mengatur syarat sebagai seorang saksi tetapi tidak mengatur secara tegas apakah saksi yang telah bersaksi sebelumnya dalam pembuatan akta oleh rekan Persekutuan Perdata Notaris kemudian digunakan kembali oleh rekan Persekutuan Perdata Notaris lainnya. ${ }^{12}$ Kedudukan saksi akta notaris sangat berbeda dengan saksi lainnya atau pada umumnya yang dimana merupakan saksi yang mendengar dan juga melihat sendiri adanya suatu kejadian yang terjadi.

Untuk para saksi akta notaris yang telah merupakan saksi akta yang dengan ini telah mengikut serta dalam adanya pembuatan akta (instrumen) atau didapati juga sebagai saksi Instrumenter (Instrumentaire Getuigen). Saksi instrumenter ialah saksi yang dalam kejadian ini merupakan para saksi yang dimana telah mengikut sertakan dalam proses terjadinya sebuah akta (instrument) itulah sebabnya saksi instrumenter dimana untuk membubuhkan sebuah tanda tangan dan juga telah memberikan sebuah kesaksian dengan benar adanya tentang sebuah kebenaran yang telah dilakukan dgn dipenuhi formalitas yang sudah diharuskan oleh undangundang didalam pasal 38 UUJNP, dan telah disaksikan oleh saksi yang ada.

Jadi dasar saksi akta ataupun yang disebut saksi instrumenter, yang dimana jika di panggil di dalam persidangan dan juga dimintai keterangan dengan ini juga bukan lagi untuk jadi saksi didalam akta tersebut, melainkan menjadi saksi secara umumnya dan dimintai keterangan yang dimana ada dalam kasus akta yang telah dibuatkannya oleh notaris itu sendiri. Dalam peristiwa ini juga bisa dilihat dalam hukum acara pidana maupun hukum acara perdata yang telah dimana mengatur tentang pembuktian mengenai suatu keterangan saksi. Secara keseluruhan maka akta yang telah dibuatkannya secara lengkap dan semua syarat telah formal dan terpenuhi hingga dimana telah mempunyai suatu kekuatan yang sangat sempurnah hingga kedudukan para saksi didalam akta juga sangat menjadi salah satu syarat yang bisa dipertanggungjawabkan dengan benar adanya.

\section{Kesimpulan dan Saran}

Berdasarkan pembahasan permasalahan yang telah diuraikan di atas, maka dapat disimpulkan Mekanisme kerja Notaris yang mencerminkan karakter Profesi Notaris terkait kerahasiaan pembuatan akta dalam menjalankan

12Marine, L. (2013). Karakteristik Hukum Perserikatan Perdata Notaris (Doctoral dissertation,

Fakultas Hukum UBAYA). 
Persekutuan Perdata Notaris menurut Pasal 16 ayat (1) huruf (f) dan Pasal 20 ayat (1) UUJNP adalah masih terdapat kekaburan norma hukum dan Keabsahan saksi Instrumenter yang sebelumnya telah bersaksi dalam pembuatan akta oleh rekan Persekutuan Perdata Notaris kemudian digunakan kembali oleh rekan Persekutuan Perdata Notaris lainnya dikaji menurut Pasal 40 UUJNP masih terdapat ambiguitas atau kekaburan norma hukum dan Rekomendasi yang dapat berikan terhadap pembahasan ini yaitu disarankan kepada para pemerintah yang terkait untuk merevisi UUJNP dalam hal pengaturan mekanisme kerja Notaris yang mencerminkan karakter Profesi Notaris terkait kerahasiaan pembuatan akta dalam menjalankan Persekutuan Perdata Notaris.

\section{Daftar Pustaka / Daftar Referensi}

\section{$\underline{\text { Buku }}$}

Ali, H. Zainuddin, (2009), Metode Penelitian Hukum, Sinar Grafika, Jakarta.

Budiono, Herlien, (2013), Dasar Teknik Pembuatan Akta Notaris, Penerbit PT. Citra Aditya Bakti, Bandung.

Marzuki,Peter Mahmud, (2008), Pengantar Ilmu Hukum, Kencana Prenada Media Group,Jakarta.

Moh. Mahfud MD dalam H. Abdul Latif dan H. Hasbi Ali, (2010), Politik Hukum, Sinar Grafika, Jakarta.

\section{Jurnal}

Ida Bagus Paramaningrat Manuaba, 2017, Prinsip Kehati-Hatian Notaris Dalam Membuat Akta Autentik, Mahasiswa Magister Kenotariatan Fakultas Hukum Udayana, Bali.

I Dwi Andika Prayojana, 2017, Pelaksanaan Penyelesaian Pelanggaran Kode Etik Notaris TentangPemasangan Papan Nama Notaris Di Kota Denpasar,Mahasiswa Magister Kenotariatan Fakultas Hukum Udayana, Bali

Kindyawati, E. (2015). Tanggung Jawab Notaris Dalam Persekutuan Perdata Terhadap Pembuatan Akta. Kumpulan Jurnal Mahasiswa Fakultas Hukum.

Marine, L. (2013). Karakteristik Hukum Perserikatan Perdata Notaris (Doctoral Dissertation, Fakultas Hukum Ubaya).

Prayojana, D. A., Murni, R. R., \& Dharmawan, N. K. S. (2018). Pelaksanaan Penyelesaian Pelanggaran Kode Etik Notaris Tentang Pemasangan Papan Nama Notaris Di Kota Denpasar. Acta Comitas, 213-218. 
Sari, Y., Muljono, S., \& Kontesa, E. (2017). Kedudukan Jabatan Notaris Dalam Bentuk Persekutuan Perdata Notaris Setelah Berlakunya Undang-Undang Nomor 2 Tahun 2014 Tentang Perubahan Atas Undang-Undang Nomor 30 Tahun 2004 Tentang Jabatan Notaris (Doctoral Dissertation, Universitas Bengkulu).

Sinuhaji, Z. B. Y. (2015). Persekutuan Perdata Menurut Undang-Undang Nomor 2 Tahun 2014 Tentang Perubahan Atas Undang-Undang Nomor 30 Tahun 2004 Tentang Jabatan Notaris Dan Kitab Undang-Undang Hukum Perdata Terhadap Prinsip Kemandirian Notaris. Kumpulan Jurnal Mahasiswa Fakultas Hukum.

Yuniati, S. (2017). Mekanisme Pemberian Sanksi Terhadap Notaris Yang Melakukan Pelanggaran Kode Etik Jabatan Notaris. Jurnal Akta.

Zakhina, I. (2016). Karakteristik Dan Bentuk Persekutuan Perdata Notaris. Kumpulan Jurnal Mahasiswa Fakultas Hukum.

\section{Tesis atau Disertasi}

Syarif, A. (2017). Akibat Hukum Kepailitan Persekutuan Perdata Notaris Terhadap Notaris Persekutuan (Doctoral Dissertation, Universitas Airlangga)

Wahyu Chandra Satriana, I Made, (2013), Kebijakan Formulasi Keadilan Restoratif Dalam Sistem Peradilan Pidana, (tesis) Program Studi Magister (S2) Ilmu Hukum Universitas Udayana, Denpasar.

\section{Undang-undang}

Kitab Undang-Undang Hukum Perdata.

Undang-Undang No.2 Tahun 2014 tentang Perubahan Atas Undang-Undang Nomor 30 Tahun 2004 tentang Jabatan Notaris, Lembaran Negara Republik Indonesia Tahun 2014 Nomor 3 Tambahan Lembaran Negara Republik Indonesia Tahun 2004 Nomor 5491.

Peraturan Menteri Hukum Dan Hak Asasi Manusia Republik Indonesia Nomor M.HH.01.AH.02.12 Tahun 2010 tentang Persyaratan Menjalankan Jabatan Notaris Dalam Bentuk Perserikatan Perdata. 